\title{
Claiming Incentive Logistics at the Heavy 4th Tuban Cement Project in Indonesia: A Practical Guidance
}

\author{
Effnu Subiyanto \\ Widya Mandala Surabaya Catholic University, Indonesia \\ effnu@yahoo.com
}

\begin{abstract}
This practical research aims to be guidance for investors who intend to claiming projects' incentives offered by Indonesia's government. Many of them failed to claim such incentives due to lack documents fulfillment since preparation, they mostly unaware, when it needed just realized requiring many revisions and finally came to end-rejection. Scope of this paper is in Indonesia for investors who are in preparation-stage to do project investments. It comes to conclude that remodeling logistics' execution can successfully reduce to only $7 \%$ of logistics costs or far below than Doing Business' finding. Methodology applied was changing Incoterms to be free on board (FOB) instead of cost and freight (CFR).
\end{abstract}

Keywords. Logistics costs, Investment, Cement project, Incentives

\section{Introduction}

To anticipate future economics' surprise due to rapid economics' growth fueled by national infrastructure's projects, Indonesia today does to adjust many things. The world ranking just released by the Ease of Doing Business (EODB) has been becoming alarm and high attention as the country was targeting to the level 40 to 50 by the end 2021. But in fact, Indonesia's ranking by 2019 was at 73 over 190 countries, only one level below than EODB 2018's achievement, though based on point is 1.42 higher becoming 67.96 than score achieved in 2018.

Dwelling time that recorded the lowest score for logistics performance had widely improved. If few years ago stood over 7 days up to weeks to get berth permission while it is only requiring 3 calendar days maximum now.

However as Indonesia just recently released that economic growth stood at 5,02\% for 2019, many things should be concerning not only dwelling time but also others that possibilities to hindering investment's appetite generally.

Recently, a number of several regulations have been released by Government to invite investors. The incentives cover income tax free and tax holiday. According of Minister of Finance Regulation (PMK) No. 35/2018 and Investment Coordinating Board (BKPM) Regulation 5/2018 on Tax Holiday states that the recipients of incentives comprise 17 pioneer industries covering 153 business sectors. The tax holiday is given through three PMKs namely; (1) PMK 130/2011, (2) PMK 159/2015, and (3) PMK 35/2018. PMK 35/2018 is incentive fiscal of investments. It stated that income tax granted for $100 \%$ free and can be exempted for 5 years to 15 years and can be extended up to 20 years for strategic projects. 


\section{Literature review}

Logistics systems according Coyle (2012) is the process of planning, implementing and controlling the efficient, effective, flow and storage of raw materials, in process inventory, finished goods, services and related information from point of origin to point of consumption (including inbound, outbound, internal and external movement) for the purpose of conforming to customer requirements. Besides, definition of logistics system in Wilson (2003) states logistics is the transparency and professionalism of customs and regulatory environments as well as harmonization of standards and conformance to international or regional regulations.

Indicators for implementation of logistics systems according Wilson are (1) efficiency port; (2) procedures, inspection and maintenance of supporting documents; (3) regulation; and (4) e-business.

The importance role of the ports mentioned in Clark (2004) that port infrastructure is important to serve good movement. There are three determinants of port efficiency, such as (1) restrictions against foreign participation in cargo handling; (2) obligation services are mandatory as like pilotage, towing, tug assistance, navigation aids, berthing, waste disposal, anchorage, and other mandatory service; and (3) the absence of organized crime such as smuggling.

Along with the increasingly competition in terms of products and services at the present time, the logistics system has undergone its own evolution. Even now it is still ongoing by itself to meet the equilibrium point.

Logistics system revolution occurred in 1990 (ITB, 2007) as a fundamental change in the business or industrial processes. This condition happens throughout worldwide with United States as being the main international benchmarking. The central point of the revolution is lying on the concept of value added by customer service or additional value dedicated to customers. The impact of global logistics systems revolution has influenced high competition, opportunities for participation to broader market, deregulation of transportation systems, mergers and acquisitions (Weston, 2004).

Metamorphose logistics system within period of 1980-1990 had achieved the integration between production processes through marketing network or channel partner. This subject is now still being developed by logistics service providers into modern concept called logistics supply chain management system. In the newest supply chain management concept is carrying a payload of data and information which is more complexes and varies requiring deeper analysis.

Unit of information that must be aligned is consisting integration of production data, budget information and flow of multiple stakeholders' interests in a single business process or production.

The notable of efficient project budgets is needed due to generally limited funding. In general, to conduct projects are uncertain regarding many issues must be addressed. Construction environments, for instance a stage that is requiring lot of resources. These performance measures are governed by the ability of the organization to maintain necessary sets of "competencies" that assist in the successful execution of its construction projects. Omar and Fayek (2016) in his paper indicates that one of competence during project execution is utilizing subsidies and or incentive offered by third parties. Such discounts could be come from vendors, social, and even more might come from authorities.

Hassen et al (2011) build success several criterias executing projects that supporting Omar and Fayek (2016). Hassen has anticipated that most of project executions failed to align 
success criteria with company's success in the long-term. The criterias mentioned are project management, product success, along with market success. Part of project management itself one of it is- utilizing subsidies.

It was clear that costs, time, and quality play important role as success factor, while widely the project team be able to manage resources than has bigger chance to get success to run projects. Atkinson (1999) explicitly concerning these factors which are said The Iron Triangle.

\section{Problem statement}

Logistics in Indonesia has been in long time ago becoming the most issues as the top hurdle economy in daily nation. Distributing daily needs absolutely interact with the terms, commuting people is also will face the issue, and so far while investors will do investment in the country unavoidably will be challenged by this terminology. As the costs compensation against Indonesia's logistics had reached 27\% national GDP, every investor will think multiple times to start economics' initiative as like making new investments.

The most hurdles lie on limited infrastructure almost in entire nation. Ports are at few numbers, if available with limited supported. There are without sufficient cranes, unavailable access to and from ports, thin trestle or concrete with consequence not stand for heavy machineries for generally projects. The ironic things, tools and or vehicles for road such as trucks, heavy-trucks, special heavy-trucks are also limited with consequence expensive to be hire.

It is not only hard structure, even more, soft structure is also concerned and was being attention. Briberies, levies, fees are common and must be meet or otherwise all processes halt or stop with much higher costs to solve later.

Even though, hard and difficult investment's climate in Indonesia; however, government provides number of subsidies and or project's incentives for compensation. Much of them in taxes-trade meant discounts, deducts to omitted taxes obligations instead of making new investments in Indonesia. Type of incentive taxes are income taxes, value-added taxes, duties, share-holders taxes, import taxes with generally at range of 5\% to $35 \%$ of the amount reported.

\section{Purpose of the study}

This study aims to do remodeling logistics variables based on the heavy $4^{\text {th }}$ cement projects of the State-owned Semen Indonesia which is effectively implemented during the projects. The project was carried on at the remote area in Central Java island but in the middle of forest that limited infrastructure to be accessed, it must deal with bad quality of roads, insufficient bridges and hundreds of roads' obstacles as like banners, narrow roads, advertisement boards and even without jetty for unloading point heavy goods from sea.

To execute the project absolutely required distinguish things with complex scopes not only at technically things but also dramatically others as like social, communications skill both oral and verbal. Writing ability was also demanded as high frequency to circulate letters with multiple issues.

\section{Methodology}

This study has been thoroughly analyzed by combining semi-structured interviews with various executives and contractors. They have been gathered, selected, and analyzed for period of research by explanatory research model. This study also utilizing mixed study both in quantitative and qualitative analysis to build comprehensive practical guidance conclusion. 
In technically, as author involving at the project directly and had been authorized to supervise and operations, the position was useful to remodelling logistics' strategy. A number sequence of strategies had been planned as following:

- Evaluating project progress and development at least 45 days later;

- Defining imported machineries that should be immediately processed and preparing import documents;

- Contact and communicate with overseas suppliers informing that certain goods must be immediately prepared for shipment;

- Start proposing incentive import taxes to various ministries in Indonesia;

- Start shipment date;

- Incentive decision granted has been taken;

- Preparing notice of arrival and submit import documents to Indonesia's customs along with incentive certificates;

- Start unloading and carrying goods to the project's location;

- Dealing with inland transportation when size and weight of goods are categorizing normal; but

- Preparing multimodal or combination transportation on sea and road while size and weight are extreme and or heavy;

- Unloading at the project's location.

\section{Data}

During execution of $4^{\text {th }}$ Tuban's cement project, the project's owner purchased main machineries from 7 countries in Europe and Asia. The countries are known already proven in design and making machineries for cement plants are Germany, Belgium, Spain, Portugal, China, India and Turkey. The procurement contract was built with the EPC type which is Engineering, Procurement and Construction. Suppliers only obliged to supply engines that all processed through openly transparency tender, while the construction was done by the owner.

Due the term of delivery based FOB (free on board) had agreed by the parties, then preparing, organizing deliveries out from origin ports and selecting appropriate vessels are becoming project owner's responsibility. According the EPC contract, the buyer is obliged to arrange sea-transport from 7 main worldwide ports to the nearest destination ports of the project site which is the only single Tanjung Perak's port, Surabaya.

Cost structure of FOB delivery terms according Incoterm 2010 are: (1) insurance; (2) sea-freight charges; and (3) customs clearance or customs charges. Costs that are not formal for example ports charges and fees are responsibility to the project owner and becoming extra costs.

Sum of all three costs structure become value declaration to the Customs and becoming base calculation to pay mandatory tax obligations. The import taxes are import duty of $5 \%$, value added tax $10 \%$, and or income taxes $2.5 \%$.

The table below is total shipments of goods imported to the $4^{\text {th }}$ Tuban's project. There are only two non-European countries origin, as stated earlier which are China and India. The two-non-European is contributing for the project only $28.25 \%$ while majority imported portions are coming from European countries.

\section{1) Table 1. Data Goods Imported for Tuban $4^{\text {th }}$ Cement Project}

\begin{tabular}{cccccc}
\hline $\begin{array}{c}\text { Shipmen } \\
\text { t No }\end{array}$ & $\begin{array}{c}\text { Value of } \\
\text { goods }\end{array}$ & Vessel's name & $\begin{array}{c}\text { Port of } \\
\text { loading }\end{array}$ & $\begin{array}{c}\text { Country of } \\
\text { origin }\end{array}$ & $\begin{array}{c}\text { Cargo } \\
\text { volume } \\
\text { (CBM) }\end{array}$ \\
\hline
\end{tabular}




\begin{tabular}{|c|c|c|c|c|c|}
\hline 1 & US\$15,233 & Wanhai 510 & Chennai & China & 355.90 \\
\hline 2 & US $\$ 3,595$ & MSC Joanna & Izmir & Turkey & 83.99 \\
\hline 3 & US\$233,117 & Wanhai 503 & Antwerp & Belgium & $1,584.21$ \\
\hline 4 & US\$51,842 & $\begin{array}{l}\text { Hanjin Long } \\
\text { Beach }\end{array}$ & $\begin{array}{l}\text { Porto/Leixoe } \\
\mathrm{S}\end{array}$ & Portugal & $1,211.27$ \\
\hline 5 & US\$34,788 & $\begin{array}{l}\text { M/V Mary } \\
\text { Schulte }\end{array}$ & Bilbao & Spain & 236.41 \\
\hline 6 & US\$14,280 & $\begin{array}{l}\text { Normed } \\
\text { Rotterdam }\end{array}$ & Hamburg & Germany & $3,333.64$ \\
\hline 7 & US\$351,640 & $\begin{array}{l}\text { Normed } \\
\text { Rotterdam }\end{array}$ & Nhava Sheva & India & $2,389.67$ \\
\hline 8 & US\$195,767 & Norjan & Antwerp & Belgium & $1,330.39$ \\
\hline 9 & US $\$ 5,428$ & Kota Latif & Hamburg & Germany & 36.89 \\
\hline 10 & US\$36,013 & $\begin{array}{l}\text { Donau Trader } \\
1009 \mathrm{~s}\end{array}$ & Chennai & China & 244.74 \\
\hline 11 & US\$90,447 & MV Regine & $\begin{array}{l}\text { Porto/Leixoe } \\
\mathrm{s}\end{array}$ & Portugal & 242.41 \\
\hline 12 & US\$52,061 & $\begin{array}{l}\text { Stadt Rostock V } \\
259\end{array}$ & Bilbao & Spain & 566.91 \\
\hline 13 & US\$114,517 & MV Regine & Antwerp & Turkey & 778.23 \\
\hline 14 & US\$65,436 & $\begin{array}{l}\text { Hanjin } \\
\text { Casablanca }\end{array}$ & Nhava Sheva & India & 898.85 \\
\hline 15 & US\$21,991 & Beluga Loyalty & Chennai & China & 239.47 \\
\hline 16 & US\$9,636 & Arabia Express & Antwerp & Belgium & 104.92 \\
\hline 17 & US\$42,049 & Humber Bridge & Izmir & Turkey & 285.75 \\
\hline 18 & US\$491,519 & Beluga Loyalty & Hamburg & Germany & $5,352.37$ \\
\hline 19 & US\$12,430 & Beluga Loyalty & Bilbao & Spain & 135.35 \\
\hline 20 & US\$66,614 & Beluga Loyalty & $\begin{array}{l}\text { Porto/Leixoe } \\
\mathrm{s}\end{array}$ & Portugal & 725.39 \\
\hline 21 & US $\$ 24,228$ & Beluga Loyalty & Nhava Sheva & India & 263.82 \\
\hline 22 & US\$52,886 & Beluga Loyalty & Izmir & Turkey & 575.90 \\
\hline 23 & US\$62,772 & MV Carlo Star & Chennai & China & 683.55 \\
\hline 24 & US $\$ 3,466$ & Cape Manuel & Antwerp & Belgium & 37.74 \\
\hline 25 & US\$5,663 & MOL Admiration & Nhava Sheva & India & 61.67 \\
\hline 26 & US $\$ 2,235$ & Conti Sidney & Bilbao & Spain & 24.33 \\
\hline 27 & US $\$ 218,171$ & MV Carlo Star & Hamburg & Germany & $2,375.76$ \\
\hline 28 & US\$206 & MOL Charisma & $\begin{array}{l}\text { Porto/Leixoe } \\
\text { s }\end{array}$ & Portugal & 4.82 \\
\hline 29 & US\$8,526 & MOL Success & Nhava Sheva & India & 92.84 \\
\hline 30 & US\$14,149 & Husky Runner & Izmir & Turkey & 154.07 \\
\hline 31 & US\$5,111 & MV Racha Bhum & Antwerp & Belgium & 34.73 \\
\hline 32 & US\$137,800 & $\begin{array}{l}\text { MOL } \\
\text { Competence }\end{array}$ & $\begin{array}{l}\text { Porto/Leixoe } \\
\mathrm{s}\end{array}$ & Portugal & 500.56 \\
\hline 33 & US\$56,595 & APL Zeebrugge & Bilbao & Spain & 616.28 \\
\hline 34 & US $\$ 31,693$ & APL Poland & Hamburg & Germany & 345.11 \\
\hline
\end{tabular}




\begin{tabular}{|c|c|c|c|c|c|}
\hline 35 & US\$253,475 & Tsingtao Express & Chennai & China & $2,260.20$ \\
\hline 36 & US\$7,074 & APL Turkey & Izmir & Turkey & 77.03 \\
\hline 37 & US\$21,223 & Sofia Express & Chennai & China & 231.10 \\
\hline 38 & US\$10,591 & $\begin{array}{l}\text { Vancouver } \\
\text { Express }\end{array}$ & Antwerp & Belgium & 115.33 \\
\hline 39 & US\$46,904 & YM Uberty & $\begin{array}{l}\text { Porto/Leixoe } \\
\mathrm{s}\end{array}$ & Portugal & 644.28 \\
\hline 40 & US\$27,235 & YM Interaction & Bilbao & Spain & 308.14 \\
\hline 41 & US\$38,889 & Donau Trader & Hamburg & Germany & 423.47 \\
\hline 42 & US\$18,512 & YM Initiative & Nhava Sheva & India & 201.58 \\
\hline 43 & US\$21,554 & $\begin{array}{l}\text { Beluga } \\
\text { Revolution }\end{array}$ & Hamburg & Germany & 234.71 \\
\hline 44 & US\$49,066 & MV Trina & Izmir & Turkey & 333.44 \\
\hline 45 & US\$15,814 & Wanhai 509 & Antwerp & Belgium & 107.47 \\
\hline 46 & US\$7,074 & APL Oregon & $\begin{array}{l}\text { Porto/Leixoe } \\
\mathrm{s}\end{array}$ & Portugal & 77.03 \\
\hline 47 & US\$1,438 & MOL Celebration & Bilbao & Spain & 15.65 \\
\hline 48 & US\$1,649 & APL Pusan & Chennai & China & 17.95 \\
\hline 49 & US\$7,074 & $\begin{array}{l}\text { MOL } \\
\text { Competence }\end{array}$ & Nhava Sheva & India & 77.03 \\
\hline 50 & US\$96,083 & $\begin{array}{l}\text { Beluga } \\
\text { Recommendation }\end{array}$ & Chennai & China & $1,046.29$ \\
\hline
\end{tabular}

Source: SMGR (2018) processed by author

Note: CBM (cubic meter)

As earlier stated the most challenging executing in term of logistics is how to send all of the machineries to the project site timely with the tight schedule, affordable costs, by at the lowest risks.

Following direct exposes to project's owner was mitigated as following below figure 1. Project's owner mandatory has to finance at first insurance costs. Following responsibility are sea-freight costs, managing and monitoring shipment since notice of departure until berth to destination port in Surabaya, Indonesia. Estimation total day shipment duration from European which is the farthest to Indonesia based on practical experience required at least 30 days to 45 days since FOB date. It means that shipment duration from other origin international sea-ports are shorter than from European ports.

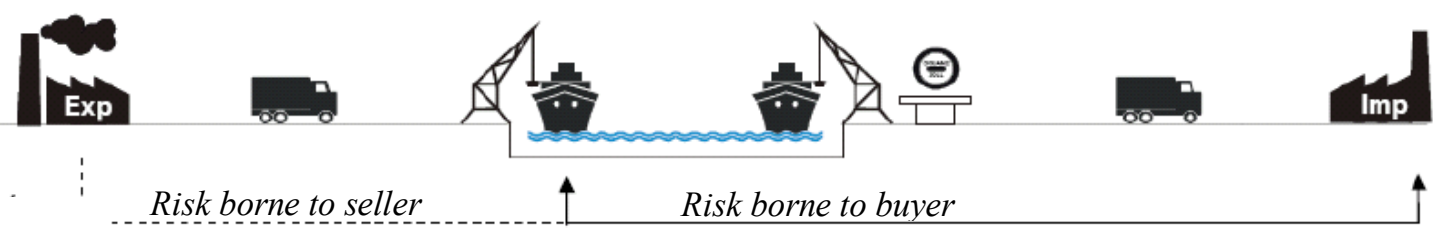

Figure 1. Risks Transfer due FOB Term

Source: Incoterms (2010)

Costs of insurance depends on the desired class of insurance's type and degree coverage. There is three kinds of insurance type available today which is Institute Cargo 
Clause (ICC) "A" to cover all risks, while other types of insurance are ICC " $B$ " and ICC "C". The last two insurance's type surely has lower insuranced degree than ICC " $A$ " coverage. Therefore amount insurance charges for ICC " $A$ " all risks will be higher than others.

\section{Utilizing Government's Investment Incentive Policies}

There are concerning many investment laws issued by Indonesia, many of them are government regulation level. According to Government Regulation 1/2007 which is first taxes incentive packages regime, investors who invest their capital in Indonesia legally has right to claim taxes incentives. The law then revised to Government Regulation 62/2008, a year after. Following year the Government Regulation to be revised again into Government Regulation 52/2011. The last Government Regulation had released to capture recent various developments and investment climate changes. Term of category has been expanded into 16 goods types starting from parts for airplanes, plastics, fertilizer, up to parts for vessels and auto-motives. Parts for cement plants are within coverage the regulations.

Main important things to claim import duty incentives are harmonizing description of goods based on description lists prior acknowledged by the Indonesia Investment Coordinating Board. The imported lists had certainly been spread into several bureaucracies' Indonesia offices which are assigned by the last Government Regulation. The group institutions were ministry of trade, ministry of industries, taxes and excise directorate general within ministry of finance, taxes directorate ministry of finance, and local customs offices where goods designated to be unloading for clearance.

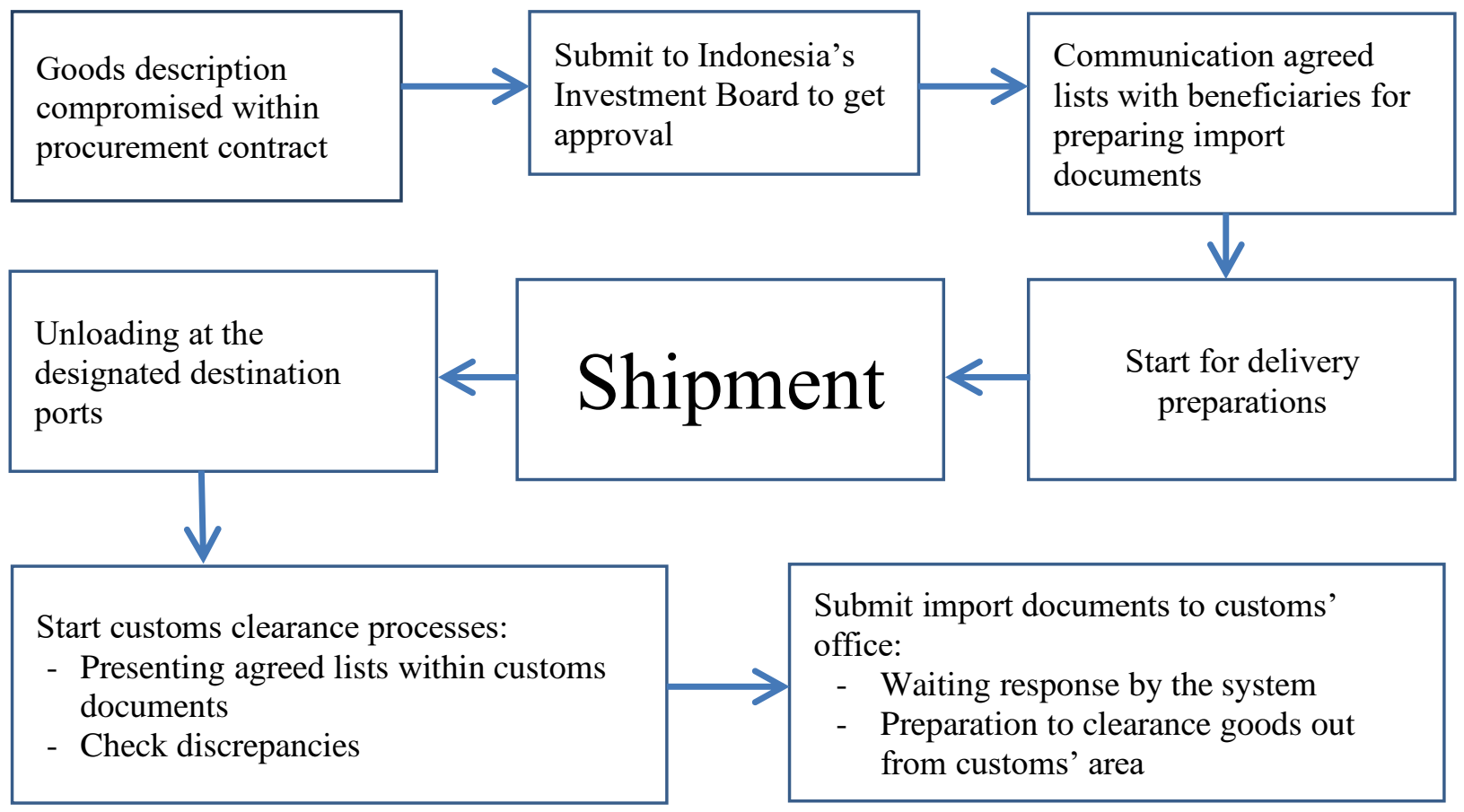

Figure 2. Processes to Claim Taxes Incentives in Indonesia due Investment

Due administered centrist policies applied in Indonesia, every investor without exception must adhere all sequential processes to acquire incentives. Amount taxes packages within regulations are waiving import duty which is minimum $5 \%$ goods value, VAT amounted $10 \%$, and import income taxes $2.5 \%$. Total amount taxes waived when all conditions and criterias meet will be at minimum $17.5 \%$. By adhere these complex procedures, sea-freight costs which 


\section{(10) IECHNIUM}

are the subject of research in this paper improved. Investors will have costs benefit that significantly important to support their investment.

The following Table 2 is concerning results to improve sea-freight costs showing impact of the Government's investment incentive policies to the logistics costs.

Table 2. Sea-freight Costs for the $4^{\text {th }}$ Tuban Cement Plant

\begin{tabular}{lrrl} 
Country of Origin & Sea-freight Cost (US\$ thousand) & Volume (CBM) & Main Port \\
\hline Belgium & 473.50 & $3,314.80$ & Antwerp \\
\hline Germany & 821.53 & $12,101.79$ & Hamburg \\
\hline India & 481.08 & $3,985.48$ & Nhava Sheva \\
\hline China & 508.44 & $5,079.23$ & Chennai \\
\hline Portugal & 400.88 & $3,405.63$ & Porto \\
\hline Spain & 186.78 & $1,903.10$ & Bilbao \\
\hline Turkey & 283.33 & $2,288.43$ & Izmir \\
\hline
\end{tabular}

\section{Empirical Analysis}

Investment decision of the $4^{\text {th }}$ Tuban Cement Plant during US-China trade war has a variety of advantages such as prices of main machineries are relatively cheaper than before. At the same time due to frequency of shipments sharply declined, then every vessels' booking relatively easy to find. Interestingly, average sea-freight tariffs are significantly lower. From 7 major international seaports where goods had been loading, Port of Hamburg showed to be the most efficient port due to the largest volume of goods shipped (see Figure 4). Influence of gravity theory for this case does not significantly take effect to the sea-freight costs.

In addition to being the most efficient port, Hamburg has received a benefit as main port of loading for all 4 vendors that supply goods and machineries for the project. Following registered vendor named Hamburg as main port is Claudius Peters, Loesche and TKF which all three had their headquarters in Germany. One other vendor is FLSmidth $\mathrm{A} / \mathrm{S}$ though headquartered in Copenhagen, Denmark but also using Hamburg port as their main port of loading its machineries they produced.

Following Figure 3 represents total volume shipped along with its total value for the $4^{\text {th }}$ Tuban Project. It shows that Germany has biggest amount volume as origin port. Germany and Europe other countires benefitted as they have capability to manufacture difficult and complex machineries (Subiyanto, 2016). Germany took gain as they are advanced in latest cement technology development. Critical cement main machineries as like grindings, mill tables, kiln shells, laboratories, gauges, instrumentations, control systems are fully supplied from Germany and countries's surrounding and shipped from Hamburg port.

While supporting machineries as like plate works, fabrications, several ductings, bag filters, cyclones and others were supplied from China and or Turkey.

It about over than $75 \%$ imported machineries for the project had been procured and supplied from European while the rest amount volume and value had been supplied by other than European.

The situations were manageable for Indonesian planner as sea logistics route is relatively countable than from China. European ports were easily to find booking or chartering vessels than other while majority lines mostly have based headquarter at the regions (John J. Coyle, 2012). With total distance from European ports to Indonesia is translated into about 45 calendar days sailing, managing cargos then lavish as preparing import documents in Indonesia generally took two weeks the soonest. 
This is totally different while cargos from China or another European countries, while sailing was requiring only 14 calendar days to reach Indonesia's ports, import documents have not ready yet and the consequence would be extra charges due demurrages costs or warehouse costs in the Indonesia's ports (Banomyong, Thai, \& Yuen, 2015). All of them will be impacting higher costs of investments in Indonesia.

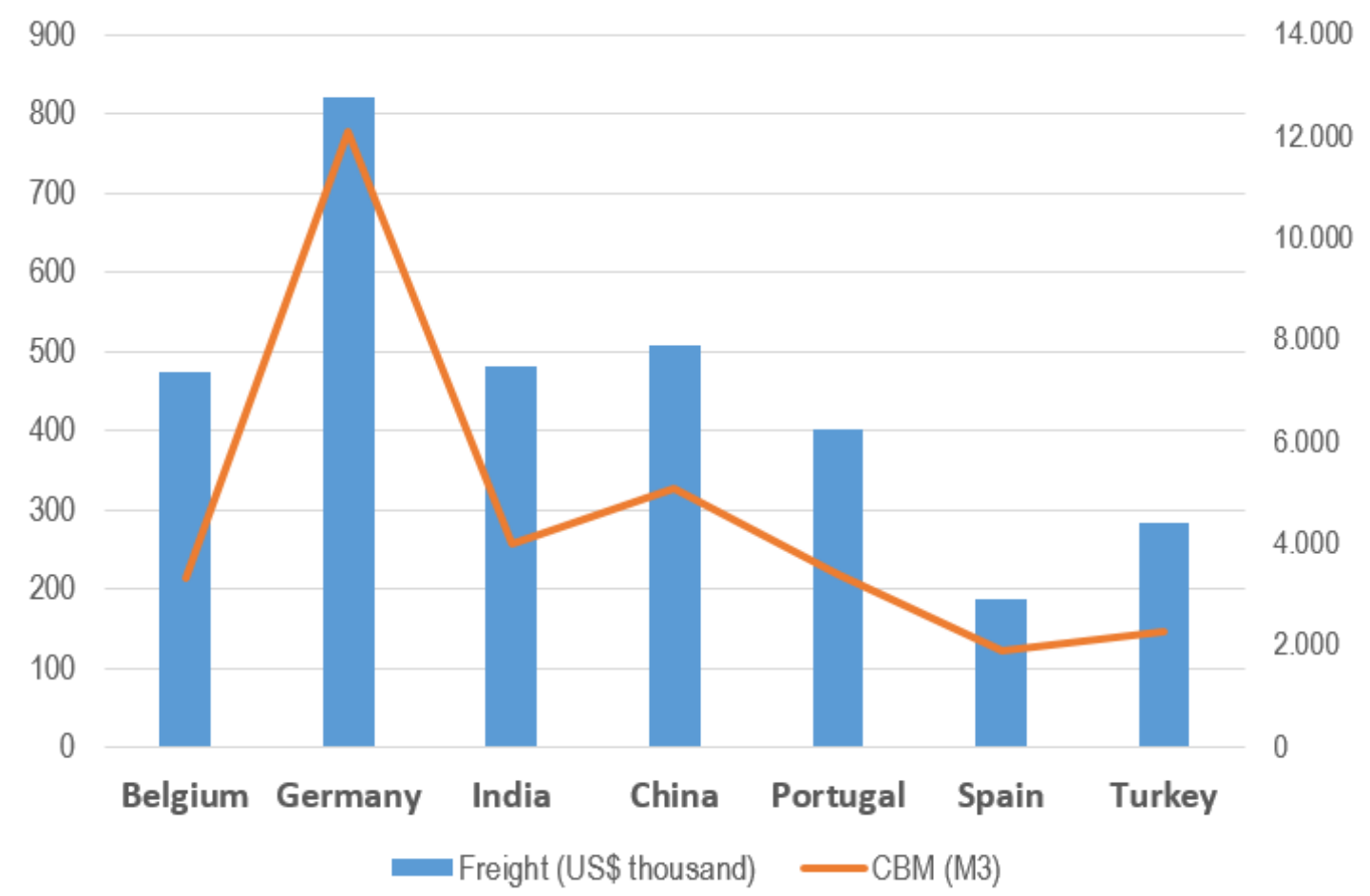

Figure 3. Total Sea-freight Costs for the New $4^{\text {th }}$ Tuban Cement Plant

According above Figure 3, by a snapshot time the total cost of sea-freight at Hamburg loading port is the highest, but it happen due to the highest amount of volume shipped among 6 other ports. This is an economics of scale applied, unit cost per CBM from Hamburg loading port ended up finally being at the cheapest price. More results can be seen at Table 3 below.

Table 3. Sea-freight Costs per CBM

\begin{tabular}{lrrlr}
\hline Country of origin & $\begin{array}{c}\text { Sea-freight (US\$ } \\
\text { thousand) }\end{array}$ & Volume (CBM) & $\begin{array}{c}\text { Original } \\
\text { ports }\end{array}$ & $\begin{array}{c}\text { Costs/CBM } \\
\text { (US\$) }\end{array}$ \\
\hline Belgium & 473.52 & $3,314.80$ & Antwerp & 142.84 \\
\hline Germany & 821.53 & $12,101.79$ & Hamburg & 67.88 \\
\hline India & 481.08 & $3,985.48$ & $\begin{array}{l}\text { Nhava } \\
\text { Sheva }\end{array}$ & 120.71 \\
\hline China & 508.44 & $5,079.23$ & Chennai & 100.10 \\
\hline Portugal & 400.89 & $3,405.63$ & Porto & 117.71 \\
\hline Spain & 186.78 & $1,903.10$ & Bilbao & 98.15 \\
\hline Turkey & 283.34 & $2,288.43$ & Izmir & 123.81 \\
\hline
\end{tabular}

Based calculation Table 3, we find that unit cost each CBM from Hamburg loading port is US\$67.88 followed by Bilbao port (US\$98.15), Chennai (US\$100.10), Porto 
(US\$117.71), Nhava Sheva (US\$120.71), Izmir (US\$123.81) and Antwerp (US\$142.84). Following Figure 4 showing all figures calculated.

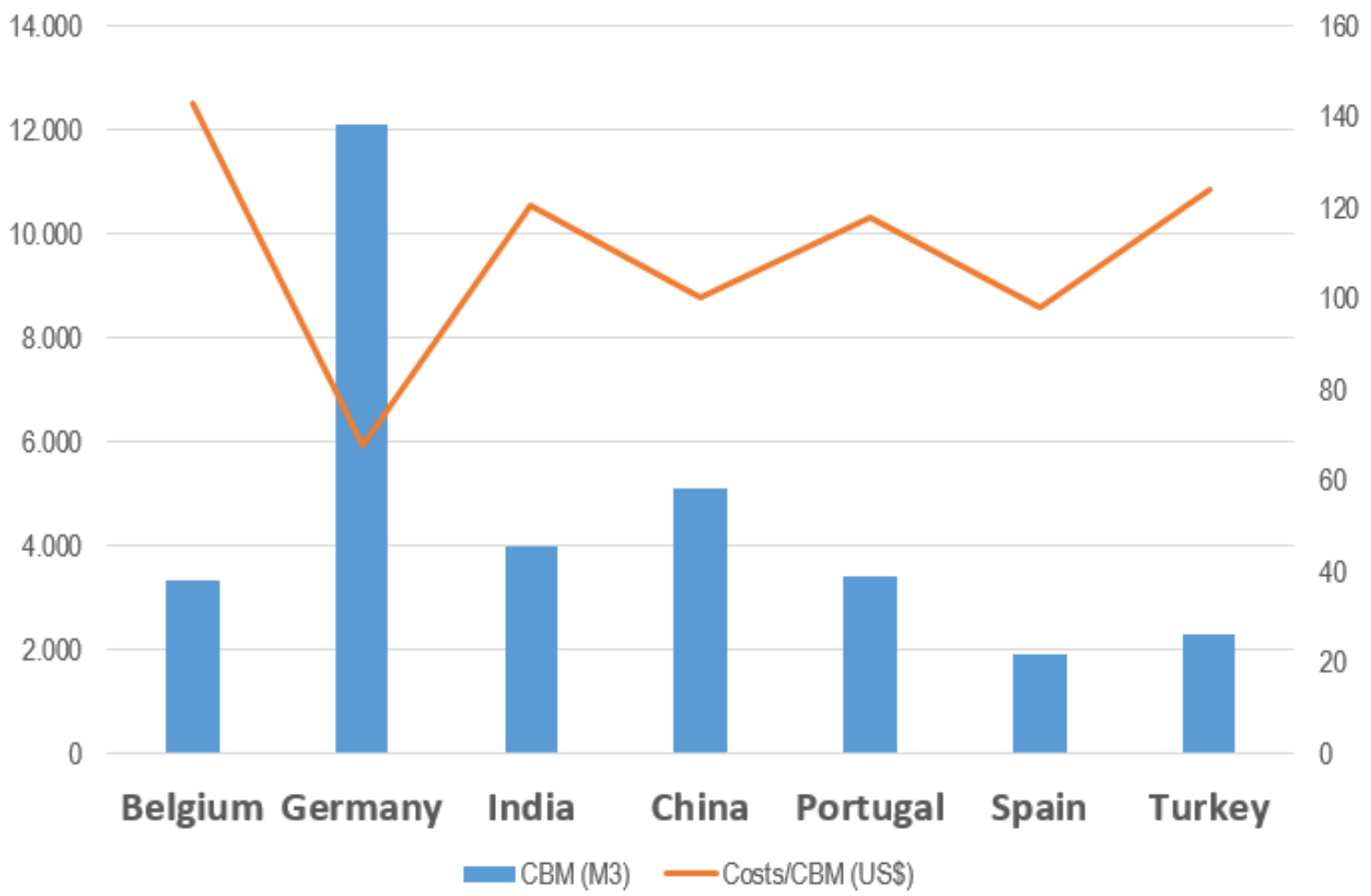

Figure 4. Hamburg Port in Germany Showed as the Cheapest Port

By above Figure 4, we can take results that investors who are able to make their cargoes within certain packing such as containers, it will get higher efficiency. This is caused the best sea-freight international packaging standards is containers. The advantages of the container packaging is not necessary requiring specialized ships, or in another word regular schedule of liner will be definitely able to take it. Break-bulk or loose packages will be impact to the sea-freight costs. These are having average fourfold higher than normal charges that apply on regular vessel.

\section{Conclusion and Future Work}

For cement plant project, choosing an efficient trading partner in terms of logistics costs is factually coming from the Hamburg Port Germany. Better infrastructure in Hamburg Port made the whole international vessels be able berthed at the port as a main call port or transit port. This made getting the vessels with international destination especially to Indonesia is not difficult. Further consequence is higher chances to get available enough space inside vessels with lower rates of sea-freight charge.

Type of cargo also affects the sea-freight costs structure and the most efficient seafreight charges is packaged in size that can be loaded in to standard containers. This is due to charges of container is fixed rate, while tariff of break-bulk cargo or loose cargo is average of fourfold higher than the normal rate using containers. Beside, break-bulk or loose cargo require such costly tramper vessel types that are not NVOCC category or non-vessel operating common carrier or non-scheduled vessel. The tramper vessel operates as charter vessel which the charge will be consequently higher or more expensive. 


\section{References}

[1] Atkinson, R. (1999). Project management: cost, time and quality, two best guesses and a phenomenon, its time to accept other success criteria. International Journal of Project Management, 337-342.

[2] Banomyong, R., Thai, V., \& Yuen, K. F. (2015). Assessing the National Logistics System of Vietnam. The Asian Journal of Shipping and Logistics, 21-58.

[3] Chen, J. N. (2011). SWOT Analysis of the Logistics Process of Shun Yue Cement Company Limited. Varkaus: Savonia University of Applied Sciences.

[4] Clark, D. D. (2004). Port efficiency, maritime transport costs, and bilateral trade. $J$ Dev Econ 75(2), 417-450.

[5] Hassen, S. M., Tmeemya, M. A., Rahman, H. A., \& Harun, Z. (2011). Future criteria for success of building projects in Malaysia. International Journal of Project Management, 337-348.

[6] ITB, L. (2007). Studi Pengembangan Sistem Logistik Nasional. Jakarta: Departemen Perhubungan.

[7] John J. Coyle, C. J. (2012). Supply Chain Management: A Logistics Perspective. Toronto: Cengage Learning.

[8] Langat, G. (2015). East Africa Logistics Performance Survey-2015. Nairobi: Leverage Consulting.

[9] OECD. (2016). Logistics Development Strategies and Performance Measurement. Paris: OECD.

[10] Omar, M. N., \& Fayek, A. R. (2016). Modeling and evaluating construction project competencies and their relationship to project performance. Automation in Construction, 115-130.

[11] Sezer, S., \& Abasiz, T. (2017). The Impact of Logistics Industry on Economic Growth: An Application in OECD Countries. Eurasian Journal of Social Sciences, 1123.

[12] Subiyanto, E. (2016). Impact of Logistics Costs to Cement Industries Investment in Indonesia. Surabaya: University of Airlangga.

[13] Vidovic, M., Kilibarda, M., Zecevic, S., \& Miljus, M. (2015). Proceedings of the 2nd Logistics International Conference. Belgrade: Logic.

[14] Weston, J. F. (2004). Takeovers, Restructuring, and Corporate Governance, 4th Edition. New Jersey, USA: Prentice Hall.

[15] Wilson, J. C. (2003). Trade Facilitation and Economic Development: Measuring the Impact. Washington D.C.: World Bank Policy Research Working Paper 2988, World Bank. 